\title{
Prevalence of antibiotic resistant Escherichia coli isolates from fecal samples of food handlers in Qatar
}

\author{
Nahla O. Eltai ${ }^{1}$, Hadi M. Yassine ${ }^{1,2}$, Asmaa A. Al Thani ${ }^{1,2}$, Marwan A. Abu Madi ${ }^{2}$ Ahmed Ismail ${ }^{3}$, Emad Ibrahim $^{4}$
} and Walid Q. Alali ${ }^{5,6^{*}}$

\begin{abstract}
Background: It is well documented that food handlers harbor and shed enteric foodborne pathogens causing foodborne disease outbreaks. However, little known on enteric antibiotic resistant (AR) bacteria carriage in food handlers. The objective of this study was to establish a baseline prevalence of fecal AR E. coli among food handlers in Qatar.

Methods: Fecal samples were collected from 456 migrant food handlers of different nationalities arriving in Qatar on a work permit between January 2015 and December 2016. These samples (25 g each) were collected based on the availability and examination schedule at the Medical Commission facility from those consented to participate. Isolated E. coli bacteria were tested for antibiotic susceptibility against nine antibiotics using the E-test method and Double Disc Synergy Test (DDST) for extended-spectrum beta-lactamase (ESBL) production.

Results: From the 78 E. coli positive samples $(17.1 \%, n=456), 60 \%$ of the isolates were resistant to at least one antibiotic, whereas, $27 \%$ were multi-drug resistant (MDR). Seven isolates $(9 \%, n=78)$ were ESBL producers of which five were MDR. Individual AR E. coli frequencies to the nine antibiotics were not significantly $(P>0.05)$ different by nationality.

Conclusions: Based on our findings, we revealed that individual resistant E. coli and MDR resistant E. coli were common in fecal samples of food handlers in Qatar. This may indicate that food handlers can potentially contaminate foods with AR E. coli, a possible public health concern.
\end{abstract}

Keywords: Food handlers, E. coli, Antibiotic resistance, Multi-drug resistant, ESBL

\section{Background}

Antibiotic resistance (AR) continues to pose a great threat to public health in both developed and developing countries $[1,2]$. Infections caused by AR bacteria, especially multi-drug resistant organisms, can lead to serious health problems such as prolonged hospitalization, treatment failure and deaths $[1,2]$. A worrying increase in multi-drug resistant phenotypes in enterobacteriaceae including E. coli and particularly to third-generation cephalosporins as well as to colistin (last resort antibiotic used

\footnotetext{
* Correspondence: walidalali@gmail.com

${ }^{5}$ College of Public Health, Hamad Bin Khalifa University, Doha, Qatar

${ }^{6}$ Present Address: Department of Veterinary Medicine, College of Food and

Agriculture, United Arab Emirates University, Alain, United Arab Emirates

Full list of author information is available at the end of the article
}

to treat carbapenem-resistant enterobacteriaceae) has been reported [3-8]. The emergence, development, and spread of AR bacteria is a complex issue that involves multiple factors such as the use and misuse of antibiotics, poor infection control practices, inadequate sanitary conditions, and inappropriate food-handling practices [9-12]. Accordingly, food handlers with poor personal hygiene and inadequate food safety knowledge working in food service establishments can be a potential source for food contamination that can lead to foodborne disease and outbreaks $[13,14]$. Likewise, food handlers who harbor AR bacteria in their gastrointestinal tract may contaminate foods which is considered as a potential route AR bacteria transmission to consumers [15].

C The Author(s). 2018 Open Access This article is distributed under the terms of the Creative Commons Attribution 4.0 International License (http://creativecommons.org/licenses/by/4.0/), which permits unrestricted use, distribution, and reproduction in any medium, provided you give appropriate credit to the original author(s) and the source, provide a link to the Creative Commons license, and indicate if changes were made. The Creative Commons Public Domain Dedication waiver (http://creativecommons.org/publicdomain/zero/1.0/) applies to the data made available in this article, unless otherwise stated. 
Food handlers have been linked to a large number of foodborne outbreaks worldwide. A total of 816 foodborne outbreaks with 80,682 foodborne illnesses occurred between 1927 and 2006 were linked to food handlers (Greig et al., 2007). Likewise, The Centre for Disease Control and Prevention (CDC) revealed that $52 \%$ of 9040 foodborne disease outbreaks reported between 1998 and 2004 were associated with food services (i.e., restaurants, cafeterias, and hotels) [16]. Approximately, bacterial agents caused $13 \%$ of these outbreaks. The majority of foodborne outbreaks associated with food services were associated with unsanitary conditions of the food handlers $[17,18]$.

Escherichia coli bacteria are very abundant in the human gastrointestinal tract and can serve as carriers/ reservoirs of AR genes. These bacteria are also able to share AR genetic material with their fellow bacteria of the same and/or different species $[19,20]$. The incidence of AR bacteria are rapidly increasing in humans in Qatar (Personal communication with the Microbiological diagnostic Laboratory of Hamad Medical Corporation, Doha, Qatar). A hospital-based AR bacteria surveillance system exists in Qatar to monitor the incidence of a number of AR bacteria from outpatient and in-patient clinics (Hamad Medical Corporation, Doha, Qatar). However, there is no available information on the AR enteric bacteria such as E. coli from non-clinical samples [21-23].

There is a large and continuous influx of migrant labor workers in Qatar; largely from south-east Asian countries [24]. A group of those migrant workers comes to Qatar on a work permit designated for jobs within the food industry such as food handling and service. Many of the food handlers have limited knowledge of risks associated with food contamination. Nonetheless, they may harbor and shed AR commensal E. coli during handling of food leading to food contamination. Hence, resistant bacteria can spread to the public through consumption of contaminated food. Research studies have shown that multi-drug resistant $E$. coli can be present in 'healthy' individual in community settings [25-29] even with the absence of antibiotic use [30]. Furthermore, several studies have revealed that AR E. coli from food source can spread to humans, colonize human gut, and potentially cause infections such as urinary tract infections [31-35].

There is currently limited information on AR phenotypes in commensal enteric organisms, from non-clinical human populations in Qatar. A first step to assess the AR risk associated with food handlers is to obtain a baseline prevalence of AR E. coli (an indicator organism) in fecal samples collected from this cohort. Therefore, the objective of this study was to determine the prevalence of the AR E. coli isolates from fecal samples of migrant food handlers in Qatar.

\section{Methods}

\section{Study population and sampling scheme}

All migrant workers including food handlers arriving to Qatar on work permit have to go through a mandatory medical screening at the Medical Commission, Department of Ministry of Public Health, Doha, Qatar [36]. Individual fecal samples were collected randomly from apparently healthy food handlers within one week of arrival to Qatar. The collection of the fecal samples was conducted between January 2015 and December 2016 as part of another research study that focused on presence of enteric parasites (Abu Madi et al., College of Health Sciences, Qatar University). All participants were provided with informed consent form explaining the purpose of the study and clearly reassured no obligation to participate; moreover, they have been comforted that all collected data will be treated with high confidentiality. The fecal samples ( $25 \mathrm{~g}$ each) were collected based on the availability and examination schedule at the Medical Commission Department from those consented to participate. Nationality information was obtained for each food handler. Portions of the fecal samples were used for the parasite analysis, while the leftover samples $(\sim 10 \mathrm{~g})$ were stored in the freezer at $-20{ }^{\circ} \mathrm{C}$. For this study, all available frozen fecal samples $(n=456)$ representing 456 food handlers collected over two year period (January 2015 to December 2016) were used i. These samples were utilized for $E$. coli isolation and antibiotic susceptibility testing. The food handlers included in this study were all males between the ages of 20 and 35 year old. There were 139, 118, $110,40,25,16,5$, and 3 fecal samples from food handlers that originated from India, Bangladesh, Nepal, Philippine, Sir Lanka, Indonesia, Kenya, and Thailand, respectively. There were no reports of acute or chronic infections in the food handlers. No additional identifiable information were available for this study. Moreover, historical antibiotic use data associated with the study subjects were not available. The Institutional Review Board (IRB) of Ministry of Public Health (Doha, Qatar) approved this study in June 2017.

\section{E. coli isolation and identification}

To isolate E. coli, fecal samples were thawed at room temperature $\left(25{ }^{\circ} \mathrm{C}\right)$, streaked directly onto a selective medium CHROMagar $^{\mathrm{rm}}$ E. coli plates (Difco, Becton Dickenson, Sparks, MD) using sterile cotton-tipped swabs, and then incubated at $37^{\circ} \mathrm{C}$ for $18-24 \mathrm{~h}$. A typical $E$. coli colony (green color with smooth surface) was randomly selected and subsequently streaked onto 5\% sheep blood agar (Difco, BD) plates, then incubated at $37{ }^{\circ} \mathrm{C}$ for $18-24$ h to obtain pure single colonies. For confirmation, suspected $E$. coli colonies were transferred onto MacConkey agar (Difco, BD) plates and incubated $\left(37^{\circ} \mathrm{C}, 18-24 \mathrm{~h}\right)$. Thereafter, colonies were streaked onto fresh blood agar plates and incubated $\left(37^{\circ} \mathrm{C}, 18-24 \mathrm{~h}\right)$ for isolation. Up to three colonies from the blood agar 
were tested for lactose fermentation using the Indole spot test (Remel, Thermoscientific, Lenexa, KS, USA). Escherichia coli isolates were transferred to Cryovial tubes (TechnicalService, Lancashire, U.K.) and stored at $-80{ }^{\circ} \mathrm{C}$ until further analysis.

\section{Antibiotic susceptibility testing of $E$. coli isolates}

Frozen E. coli isolates were revived from the Cryovials on blood agar plates. A single E. coli isolate was randomly selected from the blood agar plate and suspended in $0.85 \%$ saline (Difco, BD) to achieve an inoculum equivalent to $0.5 \mathrm{McF}$ arland standard as measured by DensiCHEK $^{\mathrm{Th}}$ Plus spectrophotometer (Biomérieux, Marcy, France). The suspension was swabbed on a Mueller-Hinton agar plate (MH; Difco, BD) using a sterile cotton-tip and allowed to dry completely at room temperature. An antibiotic susceptibility test strip (E-test strip, BioMerieux) was then applied to the MH agar surface with sterile forceps and the plate was incubated at $37{ }^{\circ} \mathrm{C}$ for $18-24 \mathrm{~h}$. Thereafter, the minimum inhibitory concentration (MIC) was read directly from the test strip where the elliptical zone of inhibition intersected with the MIC scale on the strip, according to the manufacturer's instructions. The MIC values were interpreted according to the Clinical \& Laboratory Standards Institute (CLSI) guidelines [37]. Escherichia coli strains ATCC $^{\bullet} 25,922$ and 35,218 were used as controls. The nine antibiotics utilized for antibiotic susceptibility testing of $E$. coli isolates and their breakpoints are shown in Table 1.

\section{Double disc synergy test (DDST)}

All E. coli isolates that showed resistant to 3rd generation cephalosporins (i.e., ceftriaxone in this study) with MIC $\geq 4$ based on the E-test strip results were further screened for extended-spectrum beta-lactamase (ESBL) production via the Double Disc Synergy Test (DDST) as described elsewhere [37]. Briefly, E. coli isolates from blood agar plate were suspended in $0.85 \%$ saline to achieve an inoculum equivalent to $0.5 \mathrm{McF}$ arland standard as described earlier. The suspension was then plated on an $\mathrm{MH}$ agar plate and a disc containing amoxicillin-clavulanate (20/ $\left.10 \mu \mathrm{g}, \mathrm{BD}-\mathrm{Sensi} \mathrm{Disc}^{\mathrm{m}}\right)$ was placed in the center of the plate. Next, one disc of ceftriaxone $(30 \mu \mathrm{g}, \mathrm{BD}-\mathrm{Sensi}$ Disc $\left.^{\text {th }}\right)$ and another disk of ceftazidime $(30 \mu \mathrm{g}$, BD- Sensi Disc $\left.^{\text {sin}}\right)$ were placed $15 \mathrm{~mm}$ apart from the edge of amoxicillin-clavulanate disc as shown in Fig. 1. The cefoxitin $\left(30 \mu \mathrm{g}, \mathrm{BD}-\right.$ Sensi Disc $\left.{ }^{\mathrm{Tm}}\right)$ disc was placed in any available space remaining on the plate $[37,38]$. The $\mathrm{MH}$ plates with the four antibiotic discs were incubated at $37^{\circ} \mathrm{C}$ for 18-24 h. Any E. coli isolate that showed an increase in the zone of inhibition around either ceftazidime or ceftriaxone (i.e., $>5 \mathrm{~mm}$ towards the disc of amoxicillin-clavulanate) together with susceptibility to cefoxitin was interpreted as positive for the ESBL production. Escherichia coli ATCC 51,446 and 25,922 were used as control strains for positive and negative ESBL production, respectively.

\section{Data analysis}

The antibiotic resistance outcomes (resistance or susceptible [i.e., binary]) and multidrug-resistant (MDR)

Table 1 Minimum inhibitory concentration (MIC) range and interpretation for antibiotics used to test susceptibility of E. coli isolates $(n=78)$ from food handlers' fecal samples

\begin{tabular}{|c|c|c|c|c|c|}
\hline \multirow[t]{2}{*}{ Antibiotic } & \multirow[t]{2}{*}{ Abbreviation } & \multirow[t]{2}{*}{$\mathrm{MIC}$ range tested $(\mu \mathrm{g} / \mathrm{mL})$} & \multicolumn{3}{|c|}{ MIC Interpretive Standard $(\mu \mathrm{g} / \mathrm{mL})^{\mathrm{a}}$} \\
\hline & & & & & $\mathrm{R}$ \\
\hline \multicolumn{6}{|c|}{ Penicillin \& Penicillin $\beta$-lactamase inhibitor combinations } \\
\hline Ampicillin & AM & $0.016-256$ & $\leq 8$ & 16 & $\geq 32$ \\
\hline Amoxicillin/Clavulanic acid & $X \mathrm{~L}$ & $0.016-256$ & $\leq 8 / 4$ & $16 / 8$ & $\geq 32 / 16$ \\
\hline \multicolumn{6}{|l|}{ Aminoglycosides } \\
\hline Gentamicin & GM & $0.016-256$ & $\leq 4$ & 8 & $\geq 16$ \\
\hline \multicolumn{6}{|l|}{ Quinolone } \\
\hline Ciprofloxacin & $\mathrm{Cl}$ & $0.002-32$ & $\leq 0.006$ & $0.12-0.5$ & $\geq 1$ \\
\hline \multicolumn{6}{|l|}{ Chloramphenicol } \\
\hline Chloramphenicol & $\mathrm{CL}$ & $0.016-256$ & $\leq 8$ & 16 & $\geq 32$ \\
\hline \multicolumn{6}{|l|}{ Tetracycline } \\
\hline Tetracycline & $\mathrm{TC}$ & $0.016-256$ & $\leq 4$ & 8 & $\geq 16$ \\
\hline \multicolumn{6}{|l|}{ Folate pathway inhibitors } \\
\hline Trimethoprim & $\mathrm{TR}$ & $0.002-32$ & $\leq 8$ & - & $\geq 16$ \\
\hline Sulphamethoxazole & SX & $0.064-1024$ & $\leq 258$ & & $\geq 512$ \\
\hline \multicolumn{6}{|l|}{ Cephalosporin } \\
\hline Ceftriaxone & TX & $0.016-256$ & $\leq 1$ & 2 & $\geq 4$ \\
\hline
\end{tabular}

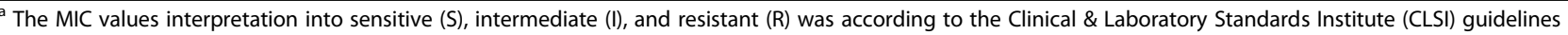




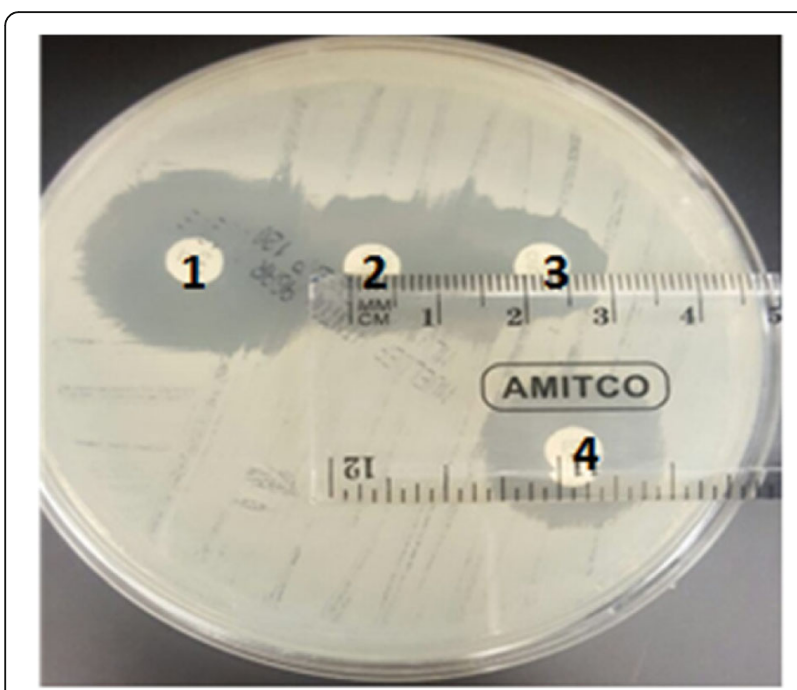

Fig. 1 Double Disc Synergy Test (DDST) confirming ESBL-Producing E. coli isolates from fecal samples of food handlers (Antibiotic discs and concentrations used were as follows: 1. Ceftazidime $(30 \mu \mathrm{g}) ; 2$. Amoxicillin/Clavulanic acid (20/10 $\mu \mathrm{g}) ; 3$. Ceftriaxone $(30 \mu \mathrm{g})$; and 4. cefoxitin $(30 \mu \mathrm{g}))$

isolates (those resistant to three or more antimicrobial classes) were cross tabulated with nationality using a Fisher's exact test or 2-by-n likelihood ratio chi-square test, as appropriate, in STATA 14.1 software (Stata Corp., College Station, TX).

\section{Results}

From the 456 food handler fecal samples tested, 78 (17.1\%) were positive for E. coli. In general, isolates were frequently resistant to sulfamethoxazole (33.3\%), followed by ampicillin (32.1\%), trimethoprim (30.8\%), and tetracycline (25.6\%). The E. coli isolates were less resistant to ciprofloxacin (14.2\%), ceftriaxone (9\%), and chloramphenicol (3.9\%).

Table 2 Distribution of fecal $E$. coli isolates $(n=78)$ by food handler's nationality

\begin{tabular}{lll}
\hline Nationality & Frequency & Percentage $^{a}$ \\
\hline Indian & 30 & 38.5 \\
Bangladesh & 19 & 24.4 \\
Nepalese & 13 & 16.7 \\
Philippine & 8 & 10.3 \\
Indonesian & 3 & 3.8 \\
Kenyan & 2 & 2.6 \\
Siri Lankan & 2 & 2.6 \\
Thai & 1 & 1.3 \\
\hline
\end{tabular}

${ }^{a}$ Percentages of antibiotic resistant $E$. coli isolates by nationality were not significantly different $(P>0.05)$ based on chi-square test in STATA 14.1 software
The distribution of $E$. coli isolates by nationality is shown in Table 2. The individual antibiotic resistant $E$. coli frequencies were not significantly $(P>0.05)$ different by nationality. The antibiotic resistance profiles among the $78 \mathrm{E}$. coli isolates are summarized in Table 3. The distribution of phenotypic antibiotic resistance to the 9 antibiotics is shown in Fig.2. Approximately, 59\% of the isolates were resistant to at least one antibiotic, whereas $11.5,15.4 \%, 11.5,11.5,6.4$ and $2.6 \%$ isolates showed resistance to one, two, three, four, five and six antibiotics, respectively (Fig. 2). Twenty-seven percent $(n=78)$ of all

Table 3 Phenotypic resistant profiles of E. coli isolates from food handlers' fecal samples $(n=78)$

\begin{tabular}{|c|c|c|}
\hline Resistant phenotype & Frequency & $\underset{c}{\text { Percentage }}$ \\
\hline No resistance & 32 & 41 \\
\hline Resistant to only one antibiotic & 9 & 11.5 \\
\hline Trimethoprim; Sulfamethoxazole & 5 & 6.4 \\
\hline Ampicillin; Trimethoprim; Sulfamethoxazole & 4 & 5.12 \\
\hline $\begin{array}{l}\text { a b Ciprofloxacin; Ampicillin; Ceftriaxone; } \\
\text { Trimethoprim; Sulfamethoxazole; Tetracycline }\end{array}$ & 2 & 2.6 \\
\hline $\begin{array}{l}\text { a Trimethoprim; Sulfamethoxazole; } \\
\text { Tetracycline; Ampicillin }\end{array}$ & 3 & 3.8 \\
\hline $\begin{array}{l}\text { a Tetracycline; Ciprofloxacin; Trimethoprim; } \\
\text { Sulfamethoxazole }\end{array}$ & 3 & 3.8 \\
\hline $\begin{array}{l}\text { a Ampicillin; Trimethoprim; Sulfamethoxazole; } \\
\text { Tetracycline; Ciprofloxacin }\end{array}$ & 2 & 2.6 \\
\hline $\begin{array}{l}\text { a b Ampicillin; Trimethoprim; Ceftriaxone; } \\
\text { Tetracycline; Ciprofloxacin }\end{array}$ & 1 & 1.3 \\
\hline $\begin{array}{l}\text { a Chloramphenicol; Sulphamethoxazole; } \\
\text { Tetracycline }\end{array}$ & 2 & 2.6 \\
\hline a Ampicillin; Trimethoprim; Tetracycline & 2 & 2.6 \\
\hline b Ampicillin; Ceftriaxone & 2 & 2.6 \\
\hline Ampicillin; Tetracycline & 2 & 2.6 \\
\hline Ampicillin; Trimethoprim & 1 & 1.3 \\
\hline Trimethoprim; Tetracycline & 1 & 1.3 \\
\hline Trimethoprim; Sulfamexazole; Ciprofloxacin & 1 & 1.3 \\
\hline $\begin{array}{l}\text { Ampicillin; trimethoprim; Sulfamethxazole; } \\
\text { Amoxcicillin-Clavulanic acid }\end{array}$ & 1 & 1.3 \\
\hline Ampicillin; Sulfamethoxazole & 1 & 1.3 \\
\hline $\begin{array}{l}\text { a b Ampicillin; Sulfamethoxazole; Ceftriaxone; } \\
\text { Ciprofloxacin }\end{array}$ & 1 & 1.3 \\
\hline $\begin{array}{l}\text { ampicillin; Trimethoprim, Sulfamethoxazole; } \\
\text { Ciprofloxacin }\end{array}$ & 1 & 1.3 \\
\hline $\begin{array}{l}\text { a b Ampicillin; Tetracycline; Trimethoprim; } \\
\text { Sulfamethoxazole; Ceftriaxone }\end{array}$ & 1 & 1.3 \\
\hline $\begin{array}{l}\text { Ampicillin; Chloramphenicol; Tetracycline; } \\
\text { Trimethoprim; Sulfamethoxazole }\end{array}$ & 1 & 1.3 \\
\hline
\end{tabular}

MDR multi drug resistant, ESBL extended spectrum beta lactamase producer ${ }^{\mathrm{a}} \mathrm{MDR}(n=19)$

${ }^{\mathrm{b}} \mathrm{ESBL}$ isolates; ESBL + MDR (21)

'Percentages of phenotypic resistant profiles of E. coli were significantly different $(P<0.05)$ based on chi-square test in STATA 14.1 software 


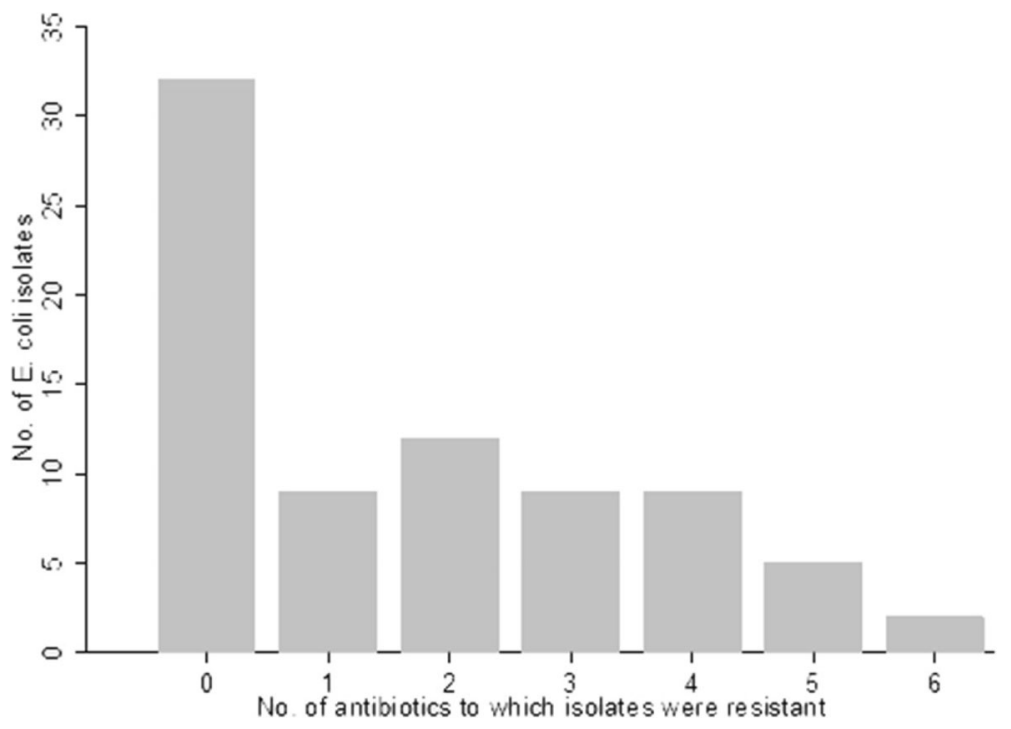

Fig. 2 Frequency bar chart illustrating the distribution of phenotypic antibiotic resistance to up to six antibiotics among $E$. coli isolates $(n=79)$ from food handlers' fecal samples in Qatar

E. coli isolates were multi drug resistant (MDR). Moreover, 9\% (seven) of the $E$. coli isolates $(n=78)$ were ESBL producers; of which five were MDR isolates.

\section{Discussion}

The incidence of AR bacteria in public hospital and clinics is monitored by the Hamad Medical Corporation (HMC), which is Qatar's main health care provider. According to recent reports by HMC, a notable increase in the incidence of AR bacteria in individuals attending out- and in-patient facilities has been observed [39, 40]. However, there are limited AR bacteria data on individuals in non-hospital (i.e., community) settings such as food handlers. To the best of our knowledge, this is the first study to investigate the prevalence of AR enteric $E$. coli in apparently healthy food handlers. In this pilot study, we reported remarkable percentages of $E$. coli isolates resistant to at least one antibiotic (i.e., 59\%) with 27\% being MDR and 9\% being ESBL producing isolates. The majority of the food handlers in this study had limited knowledge of risk associated with food contamination (personal communication with the Medical Commission staff). This group may harbor and shed AR enteric $E$. coli bacteria that can contaminate food prepared for and consumed by people in Qatar. Thus, these findings suggest that resistant $E$. coli isolates are present in the community; hence, aggravating the public health concerns regarding the spread of AR bacteria. A one-health approach ought to be considered to address this food safety and public health problem.

There are over 1300 food service establishments (restaurant and hotels) in Qatar that employ more than
50,000 workers with the majority being food handlers [41]. Food handlers have been linked to large number of foodborne outbreaks worldwide. The majority of foodborne outbreaks associated with food services are due to unsanitary conditions of the food handlers [17, 18] . Therefore, they can easily contaminate the food they handle with pathogens and non-pathogens. In agreement with our findings, several studies have shown that multi-drug resistant $E$. coli including commensal isolates harboring ESBLs can be present in healthy individuals [42-44]. Garedew-Kifelew L, Wondafrash N and Feleke A [45] examined stool specimens of food handlers from Ethiopia and revealed that $3.1 \%$ of the subjects were infected with AR Salmonella. Similarly, Greig JD, Todd EC, Bartleson CA and Michaels BS [46] concluded that most of the foodborne outbreaks were associated with food handlers who were asymptomatic carrier and excrete the pathogen unknowingly while working, or they were sick but continue to prepare food.

One of the limitations of this study was the low recovery percentage of $E$. coli from fecal sample ( $17 \%$ ) which could be due to the long storage of fecal samples in $-20{ }^{\circ} \mathrm{C}$ over 2 year period and the direct plating method of the samples on the selective medium. Another limitation was that the sample collection was from the participants conducted as part of another research study that focused on presence of enteric parasites; hence, we had no control over the sampling scheme. Moreover, the results regarding the AR E. coli by nationality need to be interpreted with caution as the number of isolates from some nationalities was low. 


\section{Conclusions}

In conclusion, food handlers that are apparently healthy individuals could harbor and shed AR enteric E. coli, posing a significant public health risk to the general population in Qatar. This may occur via dissemination of AR E. coli through contaminated food. Despite the potential effect encountered by the transmission of the opportunistic bacteria through food handlers, this is the first pilot study to screen the AR E. coli among apparently healthy food handlers. More research studies are needed to longitudinally follow AR commensal and pathogenic bacteria in food handlers and the relationship with unique and common strains found in hospital settings. A better infection control and improved food safety plans could reduce the risk of AR bacteria contamination of food in Qatar. This could be through delivering proper training to food handlers in order to prevent the contamination of foods. In addition, one-health approach with collaboration between food safety, public health, and veterinary service entities can further address this concern.

\section{Abbreviations}

AR: Antibiotic resistant; DDST: Double Disc Synergy Test; ESBL: Extendedspectrum beta-lactamase; MDR: Multi-drug resistant

\section{Funding}

This work was supported by internal funds from Hamad Bin Khalifa University to Dr. Walid Alali.

\section{Availability of data and materials}

The datasets used and/or analysed during the current study are available from the corresponding author on reasonable request.

\section{Authors' contributions}

NOE, WQA, HMY, AAA, Al, El and MAA designed the study and drafted the manuscript. NOE performed the experimental work. NOE and WQA analyzed the data. All authors read and approved the final manuscript.

\section{Ethics approval and consent to participate}

The Institutional Review Board (IRB) of Ministry of Public Health (Doha, Qatar) approved this study in June 2017.

\section{Consent for publication}

Not applicable.

\section{Competing interests}

The authors declare that they have no competing interests.

\section{Publisher's Note}

Springer Nature remains neutral with regard to jurisdictional claims in published maps and institutional affiliations.

\section{Author details}

${ }^{1}$ Biomedical Research Center, Qatar University, Doha, Qatar. ${ }^{2}$ College of Health Sciences, Qatar University, Doha, Qatar. ${ }^{3}$ Laboratory Services, Medical Commission, Ministry of Public Health, Doha, Qatar. ${ }^{4}$ Department of Lab Medicine and Pathology, Hamad Medical Hospital, Doha, Qatar. ${ }^{5}$ College of Public Health, Hamad Bin Khalifa University, Doha, Qatar. ${ }^{6}$ Present Address: Department of Veterinary Medicine, College of Food and Agriculture, United Arab Emirates University, Alain, United Arab Emirates.
Received: 15 November 2017 Accepted: 11 June 2018

Published online: 26 June 2018

\section{References}

1. WHO. Antimicrobial resistance global report on surveillance. 2014. http:// www.who.int/drugresistance/documents/surveillancereport/en/. Accessed 8 Sept 2017.

2. WHO. Global action plan on antimicrobial Resistance. 2015. http://www. wpro.who.int/entity/drug_resistance/resources/global_action_plan_eng.pdf. Accessed 14 Oct 2017

3. Burow E, Simoneit C, Tenhagen BA, Käsbohrer A. Oral antimicrobials increase antimicrobial resistance in porcine $E$. coli-a systematic review. Prev Vet Med. 2014:113:364-75.

4. Cannatelli A, Giani T, Antonelli A, Principe L, Luzzaro F, Rossolini GM. First detection of the mcr-1 colistin resistance gene in Escherichia coli in Italy. Antimicrob Agents Chemother. 2016;60:3257-8.

5. Hasman H, Hammerum AM, Hansen F, Hendriksen RS, Olesen B, Agersø Y, Zankari E, Leekitcharoenphon P, Stegger M, Kaas RS. Detection of mcr-1 encoding plasmid-mediated colistin-resistant Escherichia coli isolates from human bloodstream infection and imported chicken meat, Denmark 2015. Euro Surveill. 2015;20:1-5.

6. Poirel L, Kieffer N, Liassine N, Thanh D, Nordmann P. Plasmid-mediated carbapenem and colistin resistance in a clinical isolate of Escherichia coli. Lancet Infect Dis. 2016:16:00006-2.

7. McGann P, Snesrud E, Maybank R, Corey B, Ong AC, Clifford R, Hinkle M, Whitman T, Lesho E, Schaecher KE. Escherichia coli harboring mcr-1 and blaCTX-M on a novel IncF plasmid: first report of mcr-1 in the United States. Antimicrob Agents Chemother. 2016;60:4420-1.

8. Borg MA, Scicluna E, De Kraker M, Van De Sande-Bruinsma N, Tiemersma E, Gür D, Ben RS, Rasslan O, Elnassar Z, Benbachir M. Antibiotic resistance in the southeastern Mediterranean-preliminary results from the ARMed project. Euro Surveill. 2006;11:164-7.

9. Gould IM, Bal AM. New antibiotic agents in the pipeline and how they can help overcome microbial resistance. Virulence. 2013;4:185-91.

10. Wright GD. Something old, something new: revisiting natural products in antibiotic drug discovery 1. Can J Infect Dis. 2014;60:147-54.

11. Institute of Medicine Forum on Emerging Infections. The National Academies Collection: Reports funded by National Institutes of Health. In: Knobler SL, Lemon SM, Najafi M, Burroughs T, editors. The resistance phenomenon in microbes and infectious disease vectors: Implications for Human Health and Strategies for Containment: Workshop Summary. Washington (DC): National Academies Press (US); 2003.

12. Tanwar J, Das S, Fatima Z, Hameed S. Multidrug resistance: an emerging crisis. Interdiscip Perspect Infect Dis. 2014;2014:1-7.

13. Andargie G, Kassu A, Moges F, Tiruneh M, Huruy K. Prevalence of bacteria and intestinal parasites among food-handlers in Gondar town, Northwest Ethiopia. J Health Popul Nutr. 2008;26:451-5.

14. WHO. Health surveillance and management procedures for food-handling personnel: report of a WHO consultation [held in Geneva from 18 to 22 April 1988]. 1989. http://apps.who.int/iris/handle/10665/39610. Accessed 4 Oct 2017

15. Käferstein F, Abdussalam M. Food safety in the 21st century. Bull World Health Organ. 1999;77:347

16. Angulo FJ, Jones TF, Angulo FJ. Eating in restaurants: a risk factor for foodborne disease? Clin Infect Dis. 2006:43:1324-8.

17. Egan MB, Raats MM, Grubb SM, Eves A, Lumbers ML, Dean MS, Adams MR. A review of food safety and food hygiene training studies in the commercial sector. Food Control. 2007;18:1180-90.

18. Shinbaum S, Crandall PG, O'Bryan CA. Evaluating your obligations for employee training according to the food safety modernization act. Food Control. 2016:60:12-7.

19. Bennett PM. Plasmid encoded antibiotic resistance: acquisition and transfer of antibiotic resistance genes in bacteria. Br J Pharmacol. 2008;153:S347-57.

20. Huddleston JR. Horizontal gene transfer in the human gastrointestinal tract: potential spread of antibiotic resistance genes. Infect Drug Resist. 2014;7:167-76

21. Khan FY, Elshafie SS, Almaslamani M, Abu-Khattab M, El Hiday AH, Errayes M, Almaslamani E. Epidemiology of bacteraemia in Hamad general hospital, Qatar: a one year hospital-based study. Travel Med Infect Dis. 2010;8:377-87.

22. Rolain JM, Loucif L, Al-Maslamani M, Elmagboul E, Al-Ansari N, Taj-Aldeen S, Shaukat A, Ahmedullah $\mathrm{H}$, Hamed M. Emergence of multidrug-resistant 
Acinetobacter baumannii producing OXA-23 Carbapenemase in Qatar. New Microbes New Infect. 2016;11:47-51.

23. Samawi A, Saad M, Khan FY, Eldeeb Y, Almaslamani M, Alkhal A, Alsoub H, Ghadban W, Howady F, Hashim S. Acinetobacter infections among adult patients in Qatar: a 2-year hospital-based study. Can J Infect Dis Med Microbiol. 2016:2016:1-5.

24. Snoj J. Population of Qatar by nationality. 2017. http://priyadsouza.com/ population-of-qatar-by-nationality-in-2017/. Accessed 10 Aug 2017.

25. Pitout JDD, Nordmann P, Laupland KB, Poirel L. Emergence of Enterobacteriaceae producing extended-spectrum $\beta$-lactamases (ESBLs) in the community. J Antimicrob Chemother. 2005;56:52-9.

26. Garau J, Xercavins M, Rodríguez-Carballeira M, Gómez-Vera JR, Coll I, Vidal D, Llovet T, Ruíz-Bremón A. Emergence and dissemination of quinoloneresistant Escherichia coli in the community. Antimicrob Agents Chemother. 1999:43:2736-41.

27. Ahmed SF, Ali MMM, Mohamed ZK, Moussa TA, Klena JD. Fecal carriage of extended-spectrum B-lactamases and AmpC-producing Escherichia coli in a Libyan community. Ann Clin Microbiol Antimicrob. 2014;13:1-8.

28. Al-Agamy MH, El Mahdy TS, Shibl AM. Fecal colonization with extendedSpectrum Beta-lactamase and AmpC-producing Escherichia coli. Biomed Res Int. 2016;2016:7.

29. Azap OK, Arslan H, Serefhanoglu K, Colakoglu S, Erdogan H, Timurkaynak F, Senger SS. Risk factors for extended-spectrum beta-lactamase positivity in uropathogenic Escherichia coli isolated from community-acquired urinary tract infections. Clin Microbiol Infect. 2010;16:147-51.

30. Murray BE, Mathewson JJ, DuPont HL, Ericsson CD, Reves RR. Emergence of resistant fecal Escherichia coli in travelers not taking prophylactic antimicrobial agents. Antimicrob Agents Chemother. 1990;34:515-8.

31. Linton AH, Howe K, Bennett PM, Richmond MH, Whiteside EJ. The colonization of the human gut by antibiotic resistant Escherichia coli from chickens. J Appl Bacteriol. 1977;43:465-9.

32. Carlet J. The gut is the epicentre of antibiotic resistance. Antimicrob Resist Infect Control. 2012;1:1-7.

33. Szmolka A, Nagy B. Multidrug resistant commensal Escherichia coli in animals and its impact for public health. Front Microbiol. 2013;4:258.

34. Vincent C, Boerlin P, Daignault D, Dozois CM, Dutil L, Galanakis C, ReidSmith RJ, Tellier P-P, Tellis PA, Ziebell K, et al. Food reservoir for Escherichia coli causing urinary tract infections. Emerg Infect Dis. 2010;16:88-95.

35. Hooton TM, Samadpour M. Is acute uncomplicated urinary tract infection a foodborne illness, and are animals the source? Clin Infect Dis. 2005:40:258-9.

36. Houkoomi Qatar. Medical comission procedure: keeping Qatar disease free. 2017. http://portal.www.gov.qa/wps/portal/topics/Health/ medicalcommissionprocedures. Accessed 27 Aug 2017.

37. CLSI. Clinical and Laboratory Standards Institute. Performance standards for antimicrobial susceptibility testing. M100S. 2016;26:1-129.

38. Giriyapur RS, Nandihal NW, Krishna BVS, Patil AB, Chandrasekhar MR. Comparison of disc diffusion methods for the detection of extendedspectrum beta lactamase-producing Enterobacteriaceae. J Lab Physicians. 2011;3:33.

39. Al Soub H. HMC expert warns against improper use of antimicrobial drugs. Hamad Medical Corporation news 2015. https://www.hamad.qa/EN/news/ 2015/August/Pages/HMC-Expert-Warns-Against-Improper-Use-ofAntimicrobial-Drugs.aspx. Accessed 14 Nov 2017.

40. Aly M, Balkhy HH. The prevalence of antimicrobial resistance in clinical isolates from gulf corporation council countries. Antimicrob Resist Infect Control. 2012;1:26.

41. Ministry of Development Planning and Statistics. The Annual Bulletin of Hotels and Restaurants Statistics (accommodation and food services). 2017 http://www.mdps.gov.qa/en/statistics/Statistical\%20Releases/Economic/ HotelsandRestaurants/2014/Hotels_and_Resturants_MDPS_AnBu_AE_2014. pdf. Accessed 20 May 2017.

42. Luvsansharav U-O, Hirai I, Niki M, Sasaki T, Makimoto K, Komalamisra C, Maipanich W, Kusolsuk T, Sa-Nguankiat S, Pubampen S. Analysis of risk factors for a high prevalence of extended-spectrum $\beta$-lactamase-producing Enterobacteriaceae in asymptomatic individuals in rural Thailand. J Med Microbiol. 2011;60:619-24.

43. Rahman EMA, El-Sherif RH. High rates of intestinal colonization with extended-spectrum lactamase-producing Enterobacteriaceae among healthy individuals. J Investig Med. 2011;59:1284-6.

44. Sallem RB, Slama KB, Estepa V, Jouini A, Gharsa H, Klibi N, Sáenz Y, RuizLarrea F, Boudabous A, Torres C. Prevalence and characterisation of extended-spectrum beta-lactamase (ESBL)-producing Escherichia coli isolates in healthy volunteers in Tunisia. Eur J Clin Microbiol Infect Dis. 2012;31:1511-6.

45. Garedew-Kifelew L, Wondafrash N, Feleke A. Identification of drug-resistant Salmonella from food handlers at the University of Gondar, Ethiopia. BMC Res Notes. 2014;7:545.

46. Greig JD, Todd EC, Bartleson CA, Michaels BS. Outbreaks where food workers have been implicated in the spread of foodborne disease. Part 1. Description of the problem, methods, and agents involved. J Food Prot. 2007;70:1752-61.

\section{Ready to submit your research? Choose BMC and benefit from:}

- fast, convenient online submission

- thorough peer review by experienced researchers in your field

- rapid publication on acceptance

- support for research data, including large and complex data types

- gold Open Access which fosters wider collaboration and increased citations

- maximum visibility for your research: over $100 \mathrm{M}$ website views per year

At BMC, research is always in progress.

Learn more biomedcentral.com/submissions 